\title{
Aspek Hukum Standarisasi Produk di Indonesia dalam Rangka Masyarakat Ekonomi ASEAN
}

\author{
Deviana Yuanitasari dan Helitha Novianty Muchtar \\ Fakultas Hukum Universitas Padjadjaran Bandung \\ Jln. Dipati Ukur No. 35 Bandung \\ deviana.yuanitasari@unpad.ac.id, helitha.novianty@unpad.ac.id
}

Received: 23 Desember 2017; Accepted: 8 Juni 2018; Published: 17 Januari 2019

DOI: 10.20885/iustum.vol25.iss3.art6

\begin{abstract}
Standardization is an important aspect for Indonesia in global market competition, especially in the MEA (ASEAN Economic Community). This study raises the issues of, first, the strategy to improve product quality through Product Standardization in Indonesia in relation to MEA from the perspective of consumer protection law. Second, how ASEAN MRA (Mutual Recognition Arrangement) is adopted by ASEAN countries in the framework of MEA. The method used in this study is a normative juridical method, which includes research on positive legal inventory, research on legal principles, and in concreto legal research as well as legal comparisons. The results indicate that, first, the strategy to improve product quality through national product standardization is done by harmonizing national regulations to accelerate trade relations and protection of the Southeast Asian market. Second, ASEAN MRA is adopted by ASEAN countries with the use of MRA at the regional level, which can be seen in practice in ASEAN. The MRA concept is used by ASEAN through the ASEAN Framework Agreement on Mutual Recognition Arrangements that is currently contained in the ASEAN MRA used to support the AFTA free trade regime that was established to actualize trade liberalization among ASEAN countries.
\end{abstract}

Keywords: Standardization; MEA; ASEAN

\section{Abstrak}

Standardisasi merupakan aspek penting bagi Indonesia dalam persaingan pasar global, khususnya di MEA (Masyarakat Ekonomi ASEAN). Penelitian ini mengangkat permasalahan: pertama, bagaimana strategi peningkatan kualitas produk melalui Standardisasi Produk di Indonesia dikaitkan dengan MEA dalam perspektif hukum perlindungan konsumen. Kedua, bagaimana ASEAN MRA (Mutual Recognition Arrangement) diadopsi oleh negara-negara ASEAN dalam rangka MEA. Metode yang digunakan dalam penelitian ini merupakan metode yuridis normatif meliputi penelitian inventarisasi hukum positif, penelitian terhadap asas-asas hukum dan penelitian hukum in concreto serta perbandingan hukum. Hasil penelitian ini menyimpulkan bahwa pertama, strategi peningkatan kualitas produk melalui standardisasi produk nasional yaitu dengan cara harmonisasi peraturan nasional untuk mempercepat hubungan perdagangan dan perlindungan pasar Asia Tenggara. Kedua, ASEAN MRA diadopsi oleh negara-negara ASEAN dengan penggunaan MRA di level regional yang dapat dilihat dalam praktik di ASEAN. Konsep MRA digunakan ASEAN melalui ASEAN Framework Agreement on Mutual Recognition Arrangements yang saat ini dituangkan dalam ASEAN MRA, yang digunakan untuk mendukung rejim perdagangan bebas AFTA yang dibentuk untuk mewujudkan liberalisasi perdagangan antar negara-negara ASEAN.

Kata-kata Kunci: Standardisasi; MEA; ASEAN 


\section{Pendahuluan}

Masyarakat Ekonomi ASEAN (selanjutnya disingkat MEA) yang dibentuk pada 2015 merupakan komunitas integrasi ekonomi antara Indonesia dan negara anggota ASEAN lainnya. Hal tersebut membuka berbagai peluang sekaligus jadi batu loncatan bagi Indonesia untuk memiliki posisi tawar yang kuat dalam konstelasi politik global. MEA memiliki lima pilar utama, yaitu aliran bebas barang (free flow of goods), aliran bebas jasa (free flow of sevice), aliran bebas investasi (free flow of investment), aliran bebas tenaga kerja terampil (free flow of skilled labour), dan aliran bebas modal (free flow of capital). 2015 negara anggoata ASEAN sepakat dan telah menyetujui Cetak Biru MEA 2025 akan terbangun di atas Cetak Biru MEA 2015 yang terdiri dari lima karakteristik yang saling terkait dan saling menguatkan, yaitu: (a) ekonomi yang terpadu dan terintegrasi penuh; (b) ASEAN yang berdaya saing, inovatif, dan dinamis; (c) Peningkatan konektivitas dan kerja sama sektoral; (d) ASEAN yang tangguh, inklusif, serta berorientasi dan berpusat pada masyarakat; dan (e) ASEAN yang global. MEA 2015 bertujuan meningkatkan kesejahteraan ASEAN yang memiliki karakteristik sebagai pasar dan basis produksi tunggal, kawasan ASEAN yang lebih dinamis dan berdaya saing, memiliki pembangunan yang setara, serta mempercepat keterpaduan ekonomi di kawasan ASEAN dan dengan kawasan di luar ASEAN. ${ }^{1}$

MEA bertujuan untuk memperkecil kesenjangan antara negara-negara ASEAN dalam hal pertumbuhan perekonomian. ${ }^{2}$ Beberapa hal menjadi fokus dari MEA di 2015, salah satunya adalah MEA akan dibentuk sebagai kawasan ekonomi dengan tingkat kompetisi yang tinggi. Untuk menjamin terciptanya tingkat persaingan yang tinggi dan adil, MEA membentuk sebuah kebijakan berupa perlindungan konsumen yang juga menjamin adanya arus informasi yang akurat di pasar barang dan jasa.

\footnotetext{
1 Sekretariat Nasional ASEAN-Indonesia, "Latar Belakang Pilar Masyarakat Ekonomi ASEAN", http://setnas-asean.id/pilar-ekonomi, diakses pada tanggal 10 Januari 2018.

2 Suppanunta Romprasert, "Asian Economic Community with Selected Macroeconomic Variables for Exports Sustainability”, International Journal of Economics and Financial Issues, Vol. 3, No. 3, 2013, hlm. 602-605
} 
Menciptakan ASEAN sebagai sebuah pasar tunggal dan kesatuan basis produksi, dimana terjadi free flow $w^{3}$ atas barang, jasa, faktor produksi, investasi dan modal serta penghapusan tarif bagi perdagangan antar negara ASEAN. Penjelasan di atas merupakan gambaran mengenai apa itu MEA. Membentuk kawasan ekonomi antar negara ASEAN yang kuat.

Persaingan produk dan jasa antar negara ASEAN akan diuji dalam sistem perdagangan negara-negara yang tergabung dalam MEA. Hal itu dimaksudkan untuk menjadikan ASEAN sebagai kawasan perekonomian yang disegani oleh dunia dan mempunyai pengaruh dalam perkembangan ekonomi dunia. Masyarakat Ekonomi ASEAN (MEA) ${ }^{4}$ akan membentuk ASEAN sebagai pasar dan basis produksi tunggal dengan integrasi ekonomi yang membuat ASEAN lebih dinamis dan kompetitif dengan mekanisme beserta langkah-langkah untuk memperkuat pelaksanaan baru yang ada inisiatif ekonomi; mempercepat integrasi regional di sektor-sektor prioritas; memfasilitasi pergerakan bisnis, tenaga kerja terampil dan bakat; dan memperkuat kelembagaan mekanisme ASEAN. Sebagai langkah awal untuk mewujudkan MEA. Dengan demikian MEA dapat menciptakan integrasi ekonomi dan mendorong investasi.

Pembentukan pasar perdagangan MEA tersebut merupakan tantangan tersendiri bagi setiap negara anggota untuk meningkatkan mutu barang dan jasa. Standardisasi kemudian menjadi senjata untuk memenangkan persaingan di pasar global, terutama dalam MEA. Bagi Indonesia maupun negara-negara lain, standardisasi dinilai mampu mendorong industri untuk menghasilkan produkproduk bermutu tinggi dan berdaya saing sehingga mampu menembus pasar global.

Kendati demikian, standardisasi harus dilakukan secara komperehensif, integral dan visioner. Pasalnya standardisasi tidak dapat berdiri sendiri. Ada tiga pilar infrastruktur mutu nasional dalam standardisasi yakni metrologi, standardisasi, dan penilaian kesesuaian. Untuk hal-hal tersebut Komite Akreditasi Nasional (KAN) bertugas dan bertanggung jawab di bidang akreditasi lembaga

3 Edmund W Sim, "The Outsourcing of Legal Norms and Institutions by the ASEAN Economic Community", The Indonesian Journal of International and Comparative Law, Vol 1 Issue 1, Januari 2014

${ }^{4}$ Kazushi Shimizu, "The ASEAN Charter and the ASEAN Economic Community", Economic Journal of Hokkaido University, Vol 40, 2011, hlm. 73-87 
penilaian kesesuaian. ${ }^{5}$ Peningkatan daya saing di era globalisasi dan regionalisasi perdagangan tidak dapat dihindari lagi. Pada dasarnya hanya bangsa yang mempunyai daya saing yang tinggilah yang akan mampu memperoleh manfaat yang besar dalam meningkatkan kesejahteraannya melalui peningkatan kemampuan adaptasi dan kompetisi dalam perdagangan regional ataupun global.

Standardisasi merupakan tolak ukur perdagangan, terutama ekspor impor. Setiap negara mengharuskan adanya pengujian terhadap barang-barang yang akan diimpor maupun diekspor. Masyarakat ekonomi ASEAN harus memiliki standardisasi yang pasti dan seragam karena produk-produk dari seluruh Negara dapat masuk ke Indonesia begitu pula produk-produk Indonesia dapat masuk ke berbagai Negara ASEAN. Standardisasi dalam MEA ${ }^{6}$ ditujukan untuk memudahkan dan melindungi ekspor impor barang sehingga barang tersebut bisa bersaing dengan negara-negara lain.

Standardisasi sebagai komponen penting dalam peningkatan kualitas mutu barang dan jasa, sejatinya merupakan upaya pemenuhan hak-hak konsumen. Sehingga, standardisasi berkaitan erat dengan perlindungan konsumen. Kepentingan-kepentingan konsumen dapat terpenuhi apabila suatu produk memenuhi standardisasi yang ditetapkan oleh pemerintah, baik pemerintah nasional melalui peraturan perundang-undangan nasional atau peraturan regional yang ditetapkan oleh negara di wilayah tertentu. Upaya perlindungan konsumen tersebut harus dilakukan melalui hukum yang dapat melindungi kepentingan konsumen secara integratif dan komprehensif serta dapat diterapkan secara efektif di masyarakat. Oleh karena itu, perlindungan konsumen melalui standardisasi harus menjadi perhatian penting dalam proses produksi.

Pengaturan tentang standar produk di Indonesia, terdapat dalam UndangUndang No. 20 Tahun 2014 tentang Standardisasi dan Penilaian Kesesuaian yang dikawal oleh Badan Standardisasi Nasional (BSN). BSN ditugaskan untuk mengkoordinasikan penyusunan Standar Nasional Indonesia (SNI) dan

\footnotetext{
5 Badan Standardisasi Nasional, Pengantar Standardisasi, Edisi Pertama, Badan Standardisasi Nasional, Jakarta, 2009, hlm. 12

${ }^{6}$ Veredigna M Ledda, “AEC 2015:Issues and Challenges in Standards and Conformance”, Phillipine Journal of Development, Number 71 Vol XXXIX No. 1 \& 2, 2012
} 
menginformasikan kepada masyarakat tentang pentingnya SNI dalam produk dan sertifikasi akeditasi pada jasa. Selain produk industri besar, juga terdapat industri kecil yang telah menerapkan SNI dan mampu mengekspor produknya walaupun jumlahnya masih sedikit dibandingkan dengan industri besar. Sebetulnya ada 12 sektor prioritas standardisasi oleh 10 negara di ASEAN, namun untuk saat ini kesepakatan baru dilaksanakan pada enam sektor yaitu sektor elektronika dan kelistrikan, kayu dan produk dari kayu, karet dan produk dari karet, produk otomotif, produk kesehatan terkait produk farmasi, kosmetik, dan alat kesehatan. Adapun enam sektor lainnya akan menyusul pada agenda selanjutnya dengan sudah adanya final draft pada ASEAN Blueprint 2025. Dengan adanya pengaturan standardisasi ini, diharapkan pelaku usaha mampu meningkatkan kualitas mutu produk sehingga mampu bersaing di pasar MEA.

Meskipun di Indonesia terdapat SNI untuk menetapkan standar mutu suatu produk, namun standar tersebut bukan standar umum yang diterapkan di negaranegara ASEAN. Ketidakseragaman standar produk diantara negara-negara di ASEAN menyebabkan sulitnya penetapan standar yang akan digunakan dalam proses perdagangan di MEA. Dampak buruk yang dapat terjadi dari penerapan standar yang tidak konsisten yakni pasar yang tertutup bagi perusahaanperusaahaan yang belum mampu mencapai standar yang sudah ditetapkan. Sehingga pasar menjadi tertutup bagi produsen-produsen yang belum mampu memenuhi standar pasar tersebut, terutama produsen Usaha Mikro, Kecil dan Menengah (UMKM) dari negara-negara berkembang di kawasan ASEAN belum mampu memenuhi standar dimaksud.

Namun demikian, di dalam hukum internasional, dikenal istilah Mutual Recognition Arrangement (MRA) 7 yaitu suatu kesepakatan pengakuan terhadap produk-produk tertentu untuk memudahkan proses ekspor-impor sehingga tidak memerlukan proses pengujian kembali karena memang sudah memakai standar yang sama. ASEAN Framework Agreement on Mutual Recognition Arrangement adalah suatu kesepakatan pengakuan terhadap produk-produk tertentu untuk memudahkan proses ekspor-impor, sehingga tidak memerlukan proses pengujian

7 Shintaro Hamanaka and Sufian Jusoh, "The Emerging ASEAN Approach to Mutual Recognition", Institute of Developing Economies, JETRO, Chiba University, 2016. 
kembali di negara ASEAN yang melakukan impor karena memang sudah memakai standar yang sama. Sehingga, menarik untuk dikaji mengenai penerapan standardisasi produk dalam kerangka perlindungan konsumen, serta mekanisme adopsi MRA di negara-negara ASEAN dalam rangka MEA .

\section{Rumusan Masalah}

Berdasarkan latar belakang masalah di atas, maka permasalahan hukum yang muncul adalah: pertama, bagaimanakah strategi peningkatan kualitas produk melalui (double) standardisasi produk di Indonesia dikaitkan dengan MEA dalam perspektif Hukum Perlindungan Konsumen? Kedua, bagaimanakah ASEAN MRA (Mutual Recognition Arrangement) diadopsi oleh negara-negara ASEAN dalam rangka MEA?

\section{Tujuan Penelitian}

Adapun tujuan penelitian ini adalah: pertama, untuk menemukan strategi peningkatan kualitas produk melalui standardisasi produk di Indonesia dikaitkan dengan MEA dan hukum Perlindungan Konsumen. Kedua, untuk mengetahui ASEAN MRA (Mutual Recognition Arrangement) diadopsi oleh negara-negara ASEAN dalam rangka MEA.

\section{Metode Penelitian}

Metode penelitian yang digunakan dalam penelitian ini menggunakan penelitian hukum normatif tidak menggunakan metode penelitian sosial karena sasaran bahan penelitian adalah bahan hukum primer dan bahan hukum sekunder serta bahan hukum tersier ynag kemudian diannalisis secara kualitatif dalam arti perumusan pembenaran melalui kualitas norma hukum itu sendiri.

Berdasarkan fokus penelitiannya, penelitian hukum dibagi menjadi beberapa jenis, yaitu penelitian hukum normatif, penelitian hukum normatif -empiris dan penelitian hukum empiris. ${ }^{8}$ Dari ketiga jenis penelitian hukum tersebut penelitian yang dilakukan oleh penulis merupakan penelitian hukum normatif karena di dalam proses analisisnya penulis berfokus pada inventarisasi hukum positif, asas-

${ }^{8}$ Abdulkadir Muhammad, Hukum dan Penelitian Hukum, Cet.1, PT. Citra Aditya Bakti, Bandung, 2004, hlm. 52. 
asas dan doktrin hukum, penemuan hukum dalam perkara in concreto, sistematik hukum, taraf sinkronisasi hukum, perbandingan hukum, dan sejarah hukum.

Sebagai penelitian hukum normatif dilakukan penelitian atas data sekunder berupa bahan-bahan hukum primer, bahan hukum sekunder dan bahan hukum tersier. ${ }^{9}$ Spesifikasi penelitian ini bersifat deskriptif analitis mengenai fakta-fakta ${ }^{10}$ termasuk di dalamnya menggambarkan peraturan-peraturan yang berlaku. ${ }^{11}$ Dengan demikian penelitian ini akan menggambarkan berbagai masalah hukum yang diperoleh melalui inventarisasi hukum positif, penemuan asas hukum dan penemuan hukum in concreto tentang harmonisasi pengaturan standardisasi produk di negara-negara ASEAN terkait MEA, yang bertujuan untuk memperoleh gambaran yang menyeluruh dan sistematis melalui suatu proses analisis dengan menggunakan peraturan hukum, asas hukum dan pengertian hukum yang berkaitan dengan objek penelitian. Penelitian ini menggunakan data-data sekunder yang didapat dengan teknik studi kepustakaan (library research) dan studi internet (online research) yang berupa bahan hukum primer, sekunder dan tersier. Untuk mendukung data sekunder juga dilakukan studi lapangan guna mencari data primer. Data yang telah dikumpulkan, diklasisfikasikan dan sortir untuk mendukung analisis data terhadap masalah-masalah mengenai harmonisasi pengaturan standardisasi produk di negara-negara ASEAN terkait MEA. Metode analisis data yang digunakan dalam penelitian ini adalah normatif kualitatif, karena penelitian ini bertitik tolak dari peraturan perundang-undangan yang ada sebagai norma hukum positif serta ditunjang oleh hasil pengumpulan data lapangan yang dilakukan. Selanjutnya penalaran dilaksanakan dengan metode deduktif, kemudian dilakukan analisis secara yuridis kualitatif, yaitu data disusun secara sistematis untuk selanjutnya dianalisis secara kualitatif, yaitu hasil yang diperoleh diwujudkan dalam bentuk uraian. ${ }^{12}$

\footnotetext{
${ }_{9}$ Soerjono Soekanto dan Sri Mamudji, Penelitian Hukum Normatif suatu Tinjauan Singkat, Rajawali, Jakarta, 2006, hlm. 13-14.

${ }^{10}$ Ronny Hanitijo Soemitro, Op. Cit., hlm. 22.

11 Sumadi, Metode Penelitian, CV Rajawali, Jakarta, 1988, hlm. 19.

12 Maria S.W. Sumardjono, Pedoman Pembuatan Usulan Penelitian, Yogyakarta, Fakultas Hukum Universitas Gadjah Mada, 1989, hlm. 24-25
} 


\section{Hasil Penelitian dan Pembahasan}

\section{Strategi Peningkatan Kualitas Produk melalui Standardisasi Produk Nasional dalam Rangka MEA}

Standardisasi merupakan salah satu cara bagi pelaku ekonomi khususnya produsen untuk meningkatkan nilai tambah dari produk yang dimilikinya. Kegiatan standardisasi nasional dalam konteks ini bukan hanya untuk memfasilitasi kebutuhan pemerintah dalam melindungi kepentingan warga negara dan lingkungan, tetapi juga untuk memberikan kepercayaan kepada masyarakat bahwa produk dan/atau jasa yang memenuhi persyaratan SNI memiliki nilai tambah bila dibandingkan dengan produk dan/atau jasa yang tidak memenuhi persyaratan SNI.

"A standard is a document that sets out requirements, specifications, guidelines, or characteristics that help ensure that materials, products, processes, and services are fit for their purpose. According to the International Organization for Standardization (ISO), standards help to harmonise technical specifications of products and services, make the industry more efficient, and break down barriers to international trade. Conformity to international standards helps reassure consumers that products are safe, efficient, and good for the environment (ISO, 2014). While standards can serve legitimate commercial and policy objectives, overly burdensome or discriminatory standards-related measures can become a barrier to trade"13

Definisi standar menurut Undang-Undang No. 20 Tahun 2014 tentang Standardisasi dan Penilaian Kesesuaian adalah "persyaratan teknis atau sesuatu yang dibakukan, termasuk tata cara dan metode yang disusun berdasarkan konsensus semua pihak/pemerintah/keputusan internasional yang terkait dengan memperhatikan syarat keselamatan, keamanan, kesehatan, lingkungan hidup, perkembangan ilmu pengetahuan dan teknologi, pengalaman, serta perkembangan masa kini dan masa depan untuk memperoleh manfaat yang sebesar-besarnya." Sedangkan standardisasi adalah "proses merencanakan, merumuskan, menetapkan, menerapkan, memberlakukan, memelihara, dan mengawasi standar yang dilaksanakan secara tertib dan bekerja sama dengan semua pemangku kepentingan."

\footnotetext{
${ }^{13}$ Samuel D Scoles, "Harmonization of Standards And Mutual Recognition Agreement On Conformity Assessment In indonesia, Malaysia, Thailand And Vietnam", ERIA Research Project Report 2015 No.15, November 2015
} 
Tujuan standardisasi salah satunya adalah mengurangi hambatan perdagangan. Dalam masa globalisasi ini masyarakat internasional berusaha keras untuk mengurangi hambatan perdagangan yang dilakukan oleh negara tertentu untuk membatasi akses pasar terhadap masuknya produk negara lain misalnya dengan menetapkan bea masuk atau menetapkan standar secara sepihak. Standar mencegah adanya hambatan perdagangan non-tarif melalui harmonisasi persyaratan (standar yang sama setidaknya setara dan membatasi standar yang berbeda), sedemikian sehingga memungkinkan terjadi kompetisi sehat. Pembeli atau konsumen yakin bahwa level mutu suatu produk, proses atau jasa yang telah diproduksi atau tersedia sesuai dengan standar yang diakui. ${ }^{14}$

Pengaturan tentang standardisasi juga diatur di dalam Peraturan Pemerintah Republik Indonesia Nomor 102 Tahun 2000 tentang Standardisasi Nasional kemudian diubah menjadi Undang-Undang Republik Indonesia Nomor 20 Tahun 2014 tentang Standardisasi Dan Penilaian Kesesuaian, yang digunakan sebagai standar teknis di Indonesia. Standar Nasional Indonesia (SNI) adalah satu-satunya standar yang berlaku secara nasional di Indonesia. SNI dirumuskan oleh panitia teknis dan ditetapkan oleh Badan Standardisasi Nasional. Agar SNI memperoleh keberterimaan yang luas antara para stakeholder, maka SNI dirumuskan dengan memenuhi WTO Code of Good Practice, yaitu ${ }^{15}$.

1. Openess (keterbukaan): Terbuka bagi agar semua stakeholder yang berkepentingan dapat berpartisipasi dalam pengembangan SNI;

2. Transparency (transparansi): Transparan agar semua stakeholder yang berkepentingan dapat mengikuti perkembangan SNI mulai dari tahap pemrograman dan perumusan sampai ke tahap penetapannya. Dan dapat dengan mudah memperoleh semua informsi yang berkaitan dengan pengembangan SNI;

3. Consensus and impartiality (konsensus dan tidak memihak): Tidak memihak dan konsensus agar semua stakeholder dapat menyalurkan kepentingannya dan diperlakukan secara adil;

4. Effectiveness and relevance: Efektif dan relevan agar dapat memfasilitasi perdagangan karena memperhatikan kebutuhan pasar dan tidak bertentangan dengan peraturan perundang-undangan yang berlaku;

5. Coherence: Koheren dengan pengembangan standar internasional agar perkembangan pasar negara kita tidak terisolasi dari perkembangan pasar

${ }^{14}$ Badan Standardisasi Nasional, Pengantar Standardisasi, Edisi Pertama, Jakarta, 2009, hlm. 12

15 W'TO TBT Agreement "Code of Good Practice", Agreement on Technical Barriers to Trade, https://www.wto.org/english/docs_e/legal_e/17-tbt_e.htm\#annexIII diakses pada tanggal 15 Januari 2018 
global dan memperlancar perdagangan internasional; dan

6. Development dimension (berdimensi pembangunan): Berdimensi pembangunan agar memperhatikan kepentingan publik dan kepentingan nasional dalam meningkatkan daya saing perekonomian nasional.

Melalui standardisasi, masyarakat dapat memiliki kepercayaan yang tinggi bahwa produk dan/atau jasa nasional yang memenuhi persyaratan SNI tersebut memiliki nilai tambah dan menjadi pilihan masyarakat. Pelaku usaha nasional akan memperoleh keuntungan ekonomi yang pada gilirannya akan mendorong pertumbuhan ekonomi nasional. Karena sifatnya untuk memberikan nilai tambah bagi produk nasional, maka peran standardisasi dalam konteks peningkatan kepercayaan pasar tidak dapat dilakukan melalui pemberlakuan SNI secara wajib, tetapi lebih memerlukan promosi dan edukasi kepada pelaku usaha tentang keuntungan untuk menerapkan SNI secara sukarela, serta keuntungan bagi masyarakat apabila memilih produk dan/atau jasa yang memenuhi persyaratan SNI. ${ }^{16}$ Oleh karena itu, di kawasan ekonomi regional negara-negara maju dilakukan pembedaan tanda antara produk yang baru memenuhi persyaratan minimum untuk perlindungan publik dan lingkungan hidup berdasaran kesesuaiannya dengan standar yang diberlakukan secara wajib atau menjadi acuan regulasi teknis, dengan tanda untuk produk yang memiliki nilai tambah.

Sebagai ilustrasi, seluruh produk yang telah memenuhi European Union (EU) Directive yang mengacu pada European Norm (EN) yang memuat persyaratan keselamatan dan pelestarian lingkungan hidup untuk diedarkan di pasar Uni Eropa ditandai dengan "CE mark". Sedangkan untuk keperluan pasar domestik negaranya sendiri yang terikat dalam Uni Eropa maka negara-negara maju anggota Uni Eropa memiliki tanda nasional, seperti German Standard (GS) mark, British Standard (BS) mark, dan tanda nasional lainnya untuk memberikan informasi bahwa produk tersebut memiliki kelebihan dibandingkan dengan produk yang hanya bertanda CE.

${ }^{16}$ Badan Standardisasi Nasional, Strategi Standardisasi Nasional 2015 - 2025, Badan Standardisasi Nasional, Jakarta, Oktober 2013 
Jumlah penduduk Indonesia mencapai 50\% dari total penduduk seluruh negara anggota ASEAN. Sehingga, Indonesia mempunyai potensi pasar domestik yang besar. Kondisi ini menyebabkan timbulnya pendapat bahwa pertumbuhan ekonomi Indonesia dapat dicapai hanya dengan memanfaatkan volume perdagangan domestik. Demikian pula banyak pendapat yang menyatakan bahwa perjanjian perdagangan global yang memposisikan standardisasi sebagai salah satu pilar utama justru merugikan posisi Indonesia, karena banyak negara yang mengincar pasar Indonesia sebagai negara tujuan ekspornya.

Kenyataan yang menunjukkan besarnya potensi pasar domestik ini menyebabkan strategi standardisasi di Indonesia sampai saat ini lebih bersifat defensif. Dengan kata lain sistem defensif pada strategi standardisasi adalah sistem pelindungan yang hanya mewajibkan suatu produk untuk dilakukan standardisasi. Titik berat kegiatan standardisasi nasional masih fokus pada pemberlakuan SNI secara wajib yang diharapkan dapat mencapai tujuan utamanya untuk melindungi kepentingan publik dan lingkungan serta mampu berfungsi sebagai hambatan teknis perdagangan secara terselubung. Strategi defensif ini, mungkin memerlukan evaluasi, paling tidak bila kita melihat pada pertumbuhan Tiongkok sebagai raksasa ekonomi dunia saat ini yang justru dicapai dengan strategi ofensif, yakni strategi yang bersifat menyerang atau sesuatu hal yang bersifat agresif, 17 meskipun Tiongkok sebagai negara dengan penduduk terbesar di dunia memiliki potensi pasar domestik yang jauh lebih besar dari Indonesia.

Indonesia sebagai anggota ASEAN, meskipun jumlah penduduk Indonesia hampir 50\% dari jumlah penduduk ASEAN tetapi Gross Domestic Product (GDP) Indonesia baru mencapai 30\% dari GDP total ASEAN. Oleh karena itu dari sudut pandang korelasi antara GDP dengan volume ekonomi pasar, sebenarnya terdapat potensi ekonomi yang besar bila Indonesia mampu menjadi negara pengekspor utama bagi anggota-anggota ASEAN lainnya.

MEA melalui pilar-pilarnya yakni aliram bebas barang dan jasa, maka perdagangan pun dilakukan dengan melampaui batas-batas umum, tanpa tarif dan penghalang. Penghapusan tarif tersebut menyebabkan standardisasi menjadi pilar

${ }^{17}$ Badan Standardisasi Nasional, "Draft Strategi standardisasi Nasional 2015-2025”, Jakarta Oktober 2013, http://bsn.go.id/uploads/download/draft_strategi_standardisasi_1.pdf, diakses pada tanggal 10 Januari 2018 
utama untuk menembus pasar regional, bahkan global. Melalui standardisasi, maka dapat mengurangi permasalahan yang disebabkan oleh berbagai jenis bentuk atau ukuran produk yang terdapat di pasar. Akibat dari ketidaksimetrisan informasi dapat mengakibatkan pilihan yang merugikan konsumen dan kegagalam pasar yang besar. Apabila pembeli tidak dapat membedakan barang yang bermutu tinggi dan bermutu rendah, maka yang dirugikan adalah produsen barang yang bermutu tinggi karena harus menopang premi harga barang tersebut. Jika premi tersebut tidak ada, dan jika biaya produksi produk bermutu tinggi melebihi biaya produksi produk bermutu rendah, maka produsen barang bermutu tinggi tersebut tidak mungkin bertahan. Produsen barang bermutu rendah akan mendesak produsen barang bermutu tinggi dari pasar dengan menjual barang dengan harga yang lebih rendah. Pasar untuk mutu tinggi akan hancur dan tidak ada jual beli pada segmen ini, sehingga mengurangi surplus yang terjadi baik pada produsen atau konsumen barang bermutu tinggi ini. ${ }^{18}$

Pemberian informasi yang tepat dengan membangun reputasi baik dan memberikan isyarat kepada konsumen terhadap barang yang bermutu merupakan solusi yang dianggap tepat untuk menyelesaikan masalah ketidaksimetrisan informasi yang didapatkan oleh konsumen. Pemberian jaminan level tertentu untuk mutu produk juga menjadi solusi lain untuk membangun informasi terkait mutu produk kepada konsumen. Intervensi pemerintah juga merupakan cara yang cukup efektif. Standar bukan merupakan satu-satunya cara untuk mengatasi permasalahan pilihan yang salah, karena strategi pemberian isyarat dari sisi pasokan dan aktivitas perlindungan dari sisi permintaan juga merupakan strategi yang efektif. Namun demikian, standar dapat menjadi cara yang lebih efektif karena standar merepresentasikan barang masyarakat, yang dapat digunakan baik oleh pemasok maupun pengguna tanpa tambahan biaya. ${ }^{19}$

Praktiknya, terdapat 105 jenis produk yang wajib diberikan standarisasi yang sebagian besar produknya adalah produk yang berhubungan dengan kesehatan dan lingkungan hidup serta sumber daya alam. Suatu produk yang sudah 
memenuhi SNI akan diberikan tanda SNI pada produknya. Apabila suatu produk tertentu telah diwajibkan SNI namun tidak memiliki tanda SNI, maka produk tersebut tidak boleh diedarkan atau diperdagangkan di wilayah Indonesia. Sementara itu, suatu produk yang berada di luar daftar yang wajib ber-SNI, tanda SNI berfungsi sebagai tanda bahwa produk tersebut memiliki keunggulan.

Produsen dari 105 produk wajib meningkatkan kualitas produk untuk memenuhi standardisasi yang diminta berdasarkan peraturan standardisasi menjadi strategi bagi produsen yang ada di Indonesia untuk bersaing di dalam pasar bebas ASEAN karena dengan meningkatkan kualitas produk hingga memenuhi standar produk-produk di Indonesia paling tidak telah memenuhi standar mutu yang diinginkan konsumen di pasar dalam negeri. Hal ini menjadi strategi karena produsen dari luar tidak akan mengetahui bagaimana standardisasi yang diminta oleh pasar Indonesia. Pada akhirnya produk dari luar yang tidak memenuhi standar akan ditolak sedangkan produk dalam negeri yang telah mengetahui dan memenuhi standar akan tetap bertahan dan lebih jauh lagi akan meningkat pada ekspor produk di pasar bebas ASEAN.

Upaya peningkatan kualitas produk Indonesia melalui standardisasi tersebut, selain untuk meningkatkan kualitas produk agar mampu bersaing di arena MEA, namun juga bentuk perlindungan konsumen. Melalui Undang-undang Nomor 8 Tahun 1999 tentang Perlindungan Konsumen (UUPK) menjadi landasan hukum bagi upaya pemberdayaan konsumen, diharapkan dapat mengantar konsumen Indonesia menjadi konsumen mandiri, meningkat harkat dan martabatnya, dan memahami hak dan kewajibannya. ${ }^{20}$ Hak-hak konsumen tersebut diatur di dalam UUPK antara lain yakni :21

1) hak atas kenyamanan, kemanan, dan keselamatan dalam mengkonsumsi barang dan/atau jasa.

2) hak untuk memilih barang dan/jasa serta mendapatkan barang dan/jasa tersebut sesuai dengan nilai tukar dan kondisi serta jaminan yang dijanjikan.22

3) hak atas informasi yang benar, jelas dan jujur mengenai kondisi dan jaminan barang dan/atau jasa.

20 Pedoman Klausula Baku di Bidang Perbankan yang Disempurnakan, Direktorat Perlindungan Konsumen, Dirjen Perdagangan Dalam Negeri, Departemen Perindustrian dan Perdagangan, 2003.

${ }^{21}$ Pasal 4 UUPK.

${ }^{22}$ Ibid. 
Standardisasi sangat erat kaitannya dengan Hukum Perlindungan Konsumen, seperti yang telah dijelaskan sebelumnya dengan mengambil contoh produk yang sudah wajib SNI apabila dipenuhi oleh produsen maka ini akan meningkatkan standar kualitas produk yang dikonsumsi oleh konsumen dan sesuai dengan Pasal 4 huruf a UUPK bahwa konsumen memiliki hak atas kenyamanan, keamanan, dan keselamatan dalam mengkonsumsi barang dan/atau jasa. Sehingga dengan adanya Standardisasi ini maka hak konsumen atas kenyamanan, keamananan dan keselamatan dalam mengkonsumsi produk tersebut menjadi terpenuhi.

\section{ASEAN MRA (Mutual Recognition Arrangement) di Adopsi oleh Negara-negara ASEAN dalam Rangka MEA}

Standar dibuat sebagai alat untuk tukar menukar informasi, memastikan kualitas, dan mencapai keinginam publik. Sebagai contoh persyaratan standar emisi dan bensin dapat memberikan kontribusi agar udara tidak terpolusi. Standar dapat meningkatkan alur informasi antara produsen dan konsumen melalui karakteristik dan kualitas produk, sehingga dapat memfasilitasi transaksi dalam pasar. Proses standardisasi dapat mengurangi biaya yang tidak dapat diprediksi. Standar berguna bagi konsumen untuk membandingkan barang-barang yang memiliki kesamaan karakteristik. Selain itu standar juga berguna untuk meningkatkan elastisitas barang substitusi di antara produk yang sejenis. ${ }^{23}$ Dengan penerapan standar tentunya akan mengurangi variasi produk sehingga dimungkinkan produksi massal yang lebih efisien. Selain itu standardisasi memberikan kepastian arah masa depan industri yang berdampak pada turunnya resiko investasi di bidang riset dan pengembangan. Penerapan standar di satu sisi merupakan sumber informasi mengenai apa yang diinginkan oleh konsumen. Standar menjadi informasi kunci dalam membuat produk sesuai dengan kebutuhan konsumen sehingga penerapan standar membuka peluang pasar bagi produsen. Keberadaan standar mempunyai efek penting terhadap inovasi. Standar menyediakan informasi yang mendorong

${ }^{23}$ John S. Wilson, Standard, Regulation and Trade (WTO Rules and Developing Country Concern), Development Trade and The WTO: A Hand Book, World Bank, Washington DC, 2002, hlm. 429 
proses inovasi dengan cara mengembangkan teknologi yang dapat membuat produk lebih baik, aman dan lebih efisien. ${ }^{24}$

Kebijakan standar mutu barang menetapkan bahwa sesama negara anggota harus saling memberikan informasi tentang standar, menerima prinsip Conformity Assesment dan/atau saling mengakui standar masing-masing negara dengan pembentukan Mutual Recognition Arrangement (MRA) dengan persyaratan adanya hak serta kewajiban yang seimbang. Secara umum dalam art III huruf c tentang Panduan Umum Resolusi PBB Nomor 39/428 - Laporan Komite kedua (A/39/789/Add.2) pada 9 April 1985, melalui U.N Guidelines for Consumer Protection, telah menetapkan seruan tentang ketentuan standardisasi produk bagi kepentingan perlindungan konsumen dengan mendorong setiap negara wajib merumuskan, mempromosikan pengembangan dan penerapan standar mutu serta keamanan produk baik secar sukarela maupun wajib pada tingkatan nasional maupun internasional. Penerapan standar tersebut harus secara periodik dilakukan pengkajian berulang-ulang.

Prinsip yang dianut dalam mempersiapkan standar harus menjamin bahwa ditetapkan sesuai dengan ketentuan dalam industri dan memenuhi pilihan serta keinginan masyarakat pada umumnya. Hal ini dilakukan agar kepentingan produsen dan konsumen dapat diperhatikan. Oleh sebab itu dalam rangka globalisasi perdagangan dunia, SNI diusahakan setara dengan standar internasional.

Terdapat kesulitan yang dihadapi Indonesia sebagai negara berkembang dalam melaksanakan prosedur penilaian kesesuaian yaitu prosedur penilaian kesesuaian membutuhkan dana yang cukup banyak, kurangnya dana mengakibatkan badan yang melakukan prosedur penilaian kesesuaian tidak banyak atau tidak ada di negara berkembang. Hal ini membuat produsen di negara berkembang harus melalukan prosedur penilaian kesesuaian terhadap produknya di luar negeri dan membuat biaya produksi menjadi naik. Meskipun telah ada lembaga yang melakukan prosedur penilaian kesesuaian, namun tidak ada jaminan bahwa sertifikat yang telah dikeluarkan oleh lembaga tersebut diterima di

${ }^{24}$ Editorial, "Special Report: Kontribusi Standardisasi Terhadap Ekonomi”, Majalah SNI Valuasi Vol. 3 No. 2 Tahun 2009, Badan Standardisasi Nasional. 
negara tujuan ekspor. Kesepakatan mengenai saling pengakuan penilaian kesesuaian ada dua macam yaitu yang bersifat multilateral disebut dengan Multilateral Recognition Arrangement dan bersifat bilateral disebut dengan Mutual Recognition Agreement. MRA dalam bidang standardisasi antara lain meliputi saling pengakuan atas hasil pengujian, kalibrasi, sertifikasi sistem manajemen mutu dan lain-lain dengan badan standardisasi atau institusi negara lain atau dengan organisasi standardisasi internasional dan regional. Hal tersebut sangat diperlukan untuk dapat mendukung kelancaran perdagangan internasional.

Hukum internasional mengenal istilah Mutual Recognition Arrangement (MRA) yaitu suatu kesepakatan pengakuan terhadap produk-produk tertentu untuk memudahkan proses ekspor-impor sehingga tidak memerlukan proses pengujian kembali karena memang sudah memakai standar yang sama. Sejak diperkenalkan oleh World Trade Organization (WTO), MRA, standar, peraturan teknis, dan conformity assessment menjadi sering digunakan dalam perdagangan internasional. Banyak negara yang menggunakan MRA ini dalam perdagangannya yang bersifat bilateral. Selain itu MRA juga banyak diadopsi dalam tingkatan multilateral. Penggunaan MRA di level regional dapat dilihat dalam praktik di ASEAN. Konsep MRA digunakan ASEAN melalui ASEAN Framework Agrement on Mutual Recognition Arrangements (1998), yang saat ini dituangkan dalam ASEAN MRA, yang digunakan untuk mendukung rezim perdagangan bebas AFTA (ASEAN Free Trade Area) yang dibentuk untuk mewujudkan liberalisasi perdagangan antar negara-negara ASEAN.

MRA ASEAN adalah perjanjian kerjasama yang diciptakan untuk mendukung kebebasan dan memfasilitasi pertukaran dibidang barang maupun jasa diantara Negara-negara anggota ASEAN. MRA merupakan bagian dari banyaknya perjanjian yang telah disetujui oleh semua Negara anggota ASEAN yang dibuat dalam rangka untuk mempercepat pencapaian AFAS (ASEAN Framework Agreement on Services) sebagai salah satu tonggak pemenuhan tujuan dari ASEAN Free Trade Area (AFTA). AFTA sendiri pada dasarnya juga dibuat untuk mencapai tujuan ekonomi ASEAN secara keseluruhan di bidang ekonomi, yaitu menciptakan pasar dan basis produksi tunggal, yang ditandai dengan adanya aliran bebas dari barang, jasa, dan investasi seperti yang telah diuraikan di 
Perjanjian Bali/Bali Concord II. Menurut Soedjono Dirdjosisworo, pembentukan ASEAN Free Trade Area (AFTA) memberikan kontribusi penting bagi perdagangan dunia, karena tujuan liberalisasi perdagangan regional ASEAN sejalan dengan tujuan GATT/WTO yang berdasarkan outward oriented dan akan menunjang percepatan liberalisasi perdagangan dunia. ${ }^{25}$

Penggunaan standar produk secara alamiah memang dapat berdampak terhadap pembatasan perdagangan produk, tujuannya pada dasarnya untuk memastikan bahwa setiap negara memiliki hak kedaulatan untuk menyediakan perlindungan yang maksimal. Pada prakteknya, besar kemungkinan standar yang tidak mampu dicapai oleh pelaku usaha menyebabkan pelaku usaha tidak bisa masuk pasar dan secara tidak langsung dapat menyebabkan praktek monopoli yang disebabkan standar yang tidak bisa dicapai oleh pelaku usaha, khususnya UMKM yang pada umumnya memiliki banyak kekurangan dibandingkan dengan pelaku usaha besar. Dalam hal standar produk di Indonesia, sebenarnya sudah ada mekanisme yang baik dalam penentuan standar standar nasional SNI sebagaimana tercantum di dalam Bab IV PP Standardisasi Nasional. Demikian pula halnya dalam ruang lingkup ASEAN yang sedang dalam proses harmonisasi baik dalam perdagangan barang melalui ASEAN Consultative Committee on Standards \& Quality (ACCSQ) dan dalam perdagangan jasa melalui ASEAN Framework Agreement on Services (AFAS).

MRA merupakan suatu kesepakatan saling mengakui terhadap produkproduk tertentu antar dua atau beberapa negara untuk mempermudah kegiatan impor maupun ekspor tanpa melalui dua atau beberapa kali pengujian. Secara umum MRA diperlakukan terhadap sertifikasi hasil uji (oleh Laboratorium Uji yang didasarkan pada Standar ISO 17025) dan sertifikasi produk (oleh Lembaga Sertifikasi Produk yang didasarkan pada standar ISO Guide 65). Dalam hal ini MRA mempunyai tujuan untuk memfasilitasi perdagangan dan menstimulir aktivitas ekonomi antar berbagai pihak melalui keberterimaan dalam hal satu standar, satu pengujian, satu sertifikasi dan apabila sesuai, satu penandaan.

25 Soedjono Dirdjosisworo, Kaidah-Kaidah Hukum Perdagangan Internasional (Perdagangan Multilateral) Versi Organisasi Perdagangan Dunia (World Trade Organisation) WTO, CV. Utomo, Bandung, 2004, hlm. 20 
Terbentuknya MRA dilatarbelakangi oleh terhambatnya ekspor suatu komoditi ke suatu negara akibat peraturan teknis/standar yang diberlakukan oleh negara importir, sehingga untuk menjembatani kegiatan ekspor/impor agar tidak menghadapi hambatan baik berupa tingginya biaya yang ditimbulkan dan keterlambatan sampainya barang di tangan konsumen sebagai akibat adanya pemeriksaan di pelabuhan tujuan, maka ditempuhlah MRA. Berlakunya MRA antara dua negara (Government to Government) diawali dengan ditandatanganinya MoU (Memorandum of Understanding). Selanjunya antara dua negara saling tukar menukar informasi dengan cara saling mengadakan kunjungan ke masing-masing laboratorium negara yang bersangkutan.

Terdapat beberapa persyaratan yang harus dipenuhi oleh suatu produk untuk dapat diajukan dalam MRA untuk mengidentifikasi produk-produk unggulan, yakni:

a. Tersedia standar produk yang telah sesuai (align) dengan standar internasional.

b. Telah didukung dengan Lembaga Penilaian Kesesuaian (Conformity Assessment Body) sesuai produk tersebut, seperti: Lembaga Sertifikasi Sistem Mutu dan Lingkungan, Laboratorium Penguji dan Kalibrasi, Lembaga Sertifikasi Produk, Lembaga Sertifikasi Personel.

c. Telah didukung dengan regulasi (UU, Keppres, SK Menteri dan peraturan perundangan lainnya) yang mengatur produk tersebut dari instansi yang berwenang, baik untuk kepentingan ekspor maupun impor.

Ilmu hukum membutuhkan kesesuaian dan keselarasan antara satu perundang-undangan yang satu dengan yang lainnya, penyesuaian ini dikenal dengan harmonisasi. Harmoniasi dalam hukum mencakup penyesuaian peraturan perundang-undangan, keputusan pemerintah, keputusan hakim, sistem hukum dan asas-asas hukum dengan tujuan peningkatan kesatuan hukum, kepastian hukum, keadilan dan kesebandingan, kegunaan dan kejelasan hukum tanpa mengaburkan dan mengorbnkan pluralisme hukum. ${ }^{26}$ Harmonisasi standar di ASEAN akan menciptakan kemudahan perdagangan regional antara negaranegara anggota ASEAN. Tanpa adanya upaya dan komitmen terhadap penerapan harmonisasi standar yang maksimal maka ancaman resiko global dari

26 Suhartono, "Harmonisasi Peraturan Perundang-undangan dalam Pelaksanaan Anggaran Belanja Negara”, Disertasi, Fakultas Hukum Universitas Indonesia, 2011, hlm. 94 
perdagangan bebas adalah tersingkir dari kompetisi global sehingga akan mengakibatkan melemahnya daya saing suatu bangsa yang akan mengakibatkan rentannya kemandirian bangsa tersebut karena tidak mampu bersaing dengan produk-produk dari negara-negara lain yang memiliki tingkat kualitas dan mutu yang nomor satu. Harmonisasi standar pada perjanjian perdagangan bebas regional antara negara-negara ASEAN merupakan perwujudan perjanjian perdagangan bebas antara negara-negara ASEAN (Indonesia, Thailand, Malaysia, Singapura, Filipina, Brunei Darussalam, Vietnam, Laos, dan Kamboja) memiliki kekurangan dan kelebihan. Kekurangannya, jika industri dalam negeri belum siap bersaing dengan produk-produk dari negara lainnya maka industri dalam negeri berpotensi akan gulung tikar dan tidak mampu beroperasi lagi. Maka dari itu dibutuhkan kesiapan pemerintah dalam mempersiapkan infrastruktur dan peningkatan daya saing industri harus mutlak dilakukan.

Mengharmonisasikan standar akan tercipta kesamaan kualitas produk yang dapat menjamin perlindungan konsumen karena SNI menjadi salah satu bagian instrumen vital dalam menghadapi masalah-masalah yang muncul ketika berlangsungnya globalisasi di Indonesia. Selain akan melindungi masyarakat, meningkatkan daya saing, keamanan, kesehatan dan lingkungan, SNI juga dapat menjadi pemecahan masalah yang paling ampuh dalam menghadapi proses globalisasi yang bergerak melalui proses kerjasama regional seperti CAFTA, atau maupun yang akan datang yaitu India AFTA, Kanada AFTA dan lain-lain. Harmonisasi standar akan mempercepat hubungan perdagangan dan perlindungan pasar Asia Tenggara dari produksi-produksi yang tidak berstandar. Melalui penerapan SNI diharapkan dapat meningkatkan daya saing produkproduk Indonesia sehingga mampu bersaing dengan produk-produk negara lainnya baik yang anggota ASEAN maupun yang berasal dari China. Harmonisasi standar diharapkan dapat segera dilaksanakan pada semua jenis produk yang menjadi mata dagang ASEAN untuk menciptakan kemudahan dalam arus perdagangan bebas regional ASEAN.

Langkah-langkah yang dapat dilakukan oleh Pemerintah untuk meminimalisasi kekurangan dan memaksimalkan kelebihan penerapan standar adalah: melakukan pengawasan terhadap produk ilegal yang masuk ke Indonesia 
dalam rangka untuk melindungi konsumen dan produsen dalam negeri terhadap pasar domestik; atau tarif sudah tidak relevan lagi dengan adanya CAFTA, hanya dengan diferensiasi produk dan penerapan SNI maka produk-produk Indonesia akan memiliki nilai tambah dan akan mampu bersaing dengan produk- produk dari negara-negara lainnya. SNI juga dapat dijadikan sebagai saringan masuknya dari gempuran barang-barang Impor dari berbagai dunia. Seluruh barang impor harus memenuhi SNI jika ingin beredar di Indonesia sehingga akan dapat memproteksi produk-produk dalam negeri dari serangan barang-barang Impor negara lain yang sudah mulai masuk ke pelosok daerah bahkan hampir menggerus produsen dalam negeri.

\section{Penutup}

Berdasarkan analisis di atas, dapat disimpulkan bahwa strategi peningkatan kualitas produk melalui Standardisasi Produk Nasional dalam rangka MEA yaitu dengan cara harmonisasi peraturan standardisasi nasional, karena ini akan mempercepat hubungan perdagangan dan perlindungan pasar Asia Tenggara dari produksi-produksi yang tidak berstandar melalui Penerapan Standardisasi Nasional Indonesia (SNI) diharapkan dapat meningkatkan daya saing produkproduk Indonesia sehingga mampu bersaing dengan produk-produk negara lainnya baik yang anggota ASEAN maupun yang berasal dari China. Harmonisasi peraturan standardisasi nasional diharapkan dapat segera dilaksanakan pada semua jenis produk yang menjadi mata dagang ASEAN untuk menciptakan kemudahan dalam arus perdagangan bebas regional ASEAN. Selain dengan harmonisasi standar hal yang dapat dilakukan adalah Produsen wajib meningkatkan kualitas produk untuk memenuhi standardisai yang diminta berdasarkan peraturan standardisasi, hal ini menjadi strategi bagi produsen yang ada Indonesia untuk bersaing di dalam pasar bebas ASEAN karena dengan meningkatkan kualitas produk hingga terstandardisasi produk-produk di Indonesia paling tidak telah memenuhi standar mutu yang diinginkan konsumen di pasar dalam negeri, hal ini menjadi strategi karena produsen dari luar tidak akan mengetahui bagaimana standardisasi yang diminta oleh pasar Indonesia. Pada akhirnya produk dari laur yang tidak memenuhi standar akan ditolak sedangkan 
produk dalam negari yang telah mengetahui dan memenuhi standar akan tetap bertahan dan lebih jauh lagi akan meningkat pada ekspor produk di pasar bebas ASEAN.

ASEAN MRA diadopsi oleh negara-negara ASEAN dalam rangka MEA adalah dengan penggunaan MRA di level regional yang dapat dilihat dalam praktik di ASEAN. Konsep MRA digunakan ASEAN melalui ASEAN Framework Agrement on Mutual Recognition Arrangements yang saat ini dituangkan dalam ASEAN Mutual Recognition Arrangement, yang digunakan untuk mendukung rezim perdagangan bebas AFTA yang dibentuk untuk mewujudkan liberalisasi perdagangan antar negara-negara ASEAN. Hal ini sesuai dengan salah satu pilar Visi ASEAN 2020 yaitu ASEAN Economic Community. Dalam hal ini MRA mempunyai tujuan untuk memfasilitasi perdagangan dan menstimulasi aktivitas ekonomi antar berbagai pihak melalui keberterimaan dalam hal satu standar, satu pengujian, satu sertifikasi dan apabila sesuai, satu penandaan.

\section{Daftar Pustaka}

\section{Buku}

Badan Standardisasi Nasional, Pengantar Standardisasi, Edisi Pertama, Jakarta, 2009. Strategi Standardisasi Nasional 2015 - 2025, Jakarta, 2013.

Shofie, Yusuf, Perlindungan Konsumen dan Instrumen-instrumen Hukumnya, Citra Aditya Bakti, Bandung, 2003.

Soemitro, Ronny Hanitijo, Metodologi Penelitian Hukum dan Jurimetri, Ghalia Indonesia, Jakarta, 1990.

Soekanto, Soerjono dan Sri Mamudji, Penelitian Hukum Normatif suatu Tinjauan Singkat, Rajawali, Jakarta, 2006.

Sumadi, Metode Penelitian, CV Rajawali, Jakarta, 1988.

Sumardjono, Maria S.W., Pedoman Pembuatan Usulan Penelitian, Yogyakarta, Fakultas Hukum Universitas Gadjah Mada, 1989.

Syawali, Husni dan Neni Sri Imaniyati, Hukum Perlindungan Konsumen, Mandar Maju, Bandung, 2000.

Wilson, John S., Standard Regulation and Trade (WTO Rules and Developing Country Concern), Development Trade and The WTO: A Hand Book, World Bank, Washington DC, 2002. 
Artikel, Jurnal

Editorial, "Special Report: Kontribusi Standardisasi Terhadap Ekonomi", Majalah SNI Valuasi Vol. 3 No. 2 Tahun 2009, Badan Standardisasi Nasional.

Hamanaka, Shintaro and Sufian Jusoh, "The Emerging ASEAN Approach to Mutual Recognition", Institute of Developing Economies, JETRO, Chiba University 2016.

Ledda, Veredigna M., "AEC 2015:Issues and Challenges in Standards and Conformance", Phillipine Journal of Development, Number 71 Vol XXXIX No. $1 \& 2,2012$

Scoles, Samuel D., "Harmonization Of Standards And Mutual Recognition Agreement On Conformity Assessment Inindonesia, Malaysia, Thailand And Vietnam", ERIA Research Project Report 2015 No. 15, November 2015

Shimizu, Kazushi, "The ASEAN Charter and the ASEAN Economic Community" Economic Journal of Hokkaido University, Vol. 40, 2011.

Sim, Edmund W, "The Outsourcing of Legal Norms and Institutions by the ASEAN Economic Community", The Indonesian Journal of International and Comparative Law, Vol 1 Issue 1, Januari 2014.

Romprasert, Suppanunta, "Asian Economic Community with Selected Macroeconomic Variables for Exports Sustainability," International Journal of Economics and Financial Issues, Vol. 3, No. 3, 2013.

\section{Peraturan Perundang-Undangan}

Undang-Undang Dasar Negara Republik Indonesia Tahun 1945

Undang-Undang Nomor 20 Tahun 2014 tentang Standardisasi dan Penilaian Kesesuaian (Tambahan Lembaran Negara Republik Indonesia Nomor 5584)

Peraturan Pemerintah No. 102 Tahun 2000 tentang Standardisasi Nasional (Tambahan Lembaran Negara Republik Indonesia Nomor 4020)

\section{Internet}

WTO TBT Agreement "Code of Good Practice", Agreement on Technical Barriers to Trade, https://www.wto.org/english/docs_e/legal_e/17tbt_e.htm\#annexIII diakses pada tanggal 15 Januari 2018. 